\title{
Efficacy of Genetic Sonogram For Predicting Aneuploidy In a High- Risk Pregnancy Population
}

\author{
Yüksek Riskli Gebelik Popülasyonunda Anöploidi Tahmin Etmede Genetik Sonogramın \\ Etkinliği
}

Fatma Toker Özdemir ${ }^{1}$,Bulat Aytek ŞIK ${ }^{2}$, Arzu Yılda Aba ${ }^{3}$

\begin{abstract}
Aim: This study evaluates the efficacy of genetic sonogram for predicting aneuploidy in high-risk pregnancies. Material-Methods: This retrospective study included 1363 pregnant women who underwent a second trimester genetic sonogram due to high-risk pregnancy. Sensitivity, specificity, odds ratio, (+) and (-) likelihood ratios were calculated for each of the ultrasonography markers.

Results: Among the high-risk pregnancy study population, there was no significant difference regarding advanced maternal age, presence of a relative with Down Syndrome, history of anomaly in the previous pregnancy, hyperechogenic bowels, pyelectasis, nuchal fold thickness $>5 \mathrm{~mm}$, ventriculomegaly, choroid plexus cyst, single umbilical artery or presence of right echogenic intracardiac focus between the control and aneuploidy groups ( $>0.05$ ). Tricuspid regurgitation, hypoplasia/absence of nasal bone, short femur, short humerus and left echogenic intracardiac focus were associated with increased risk of aneuploidy $(\mathrm{p}<0.05)$. The risk of aneuploidy was increased by 14.45 fold (95\% CI 2.90-71.85) in cases with tricuspid regurgitation, 18.01 (5.46-59.32) fold by hypoplasia/absence of nasal bone, 9.74 (3.70-25.65) fold by presence of short femur, 11.42 (4.30-30.30) fold by presence of short humerus, and $4.20(1.39-12.64)$ fold with the presence of left echogenic intracardiac focus. Analysis of combined markers showed that hypoplasia/absence of nasal bone + shor humerus + tricuspid regurgitation resulted in the highest risk $(\mathrm{OR}=11.20, \mathrm{LHR}=7.53)$

Conclusion: In countries where NIPT could not be used as a screening test, genetic sonography is recommended for Down syndrome risk modification in high-risk pregnancies.
\end{abstract}

Keywords: Genetic sonography, Aneuploidy, Pregnancy

\section{Öz}

Amaç: Bu çalışmanın amacı yüksek riskli gebeliklerde anöploidi öngörmede genetik sonogramın etkinliğin değerlendirmektedir.

Gereç ve Yöntem: Bu retrospektif çalışmaya yüksek riskli gebelik nedeniyle ikinci trimester genetik sonogram uygulanan 1363 gebe dahil edildi. Her bir ultrasonografi markerı için spesifite, sensivite, odds ratio, pozitif ve negatif olabilirlik oranları hesaplanmıştır.

Bulgular: Çalışmada yüksek riskli gebelik popülasyonunda; ileri anne yaşı, Down Sendromlu bir akrabanın varlığı, önceki gebelikte anomali öyküsü, hiperekojenik bağırsak, pyelektazi, ense kalınlığı $>5 \mathrm{~mm}$, ventrikülomegali, koroid pleksus kisti, tek umbilikal arter varlığı, sağ ekojenik intrakardiyak odak açısından kontrol ve anöploidi grupları arasında anlamlı bir fark yoktu ( $>0.05$ ). Triküspit yetersizliği, burun kemiği hipoplazisi/yokluğu, kısa femur, kısa humerus ve sol ekojenik intrakardiyak odak artmış anöploidi riski ile ilişkili bulunmuştur $(\mathrm{p}<0.05$ ). Anöploidi riski, triküspit yetersizliği olan olgularda $14.45 \mathrm{~kat}$ (\% 95 CI 2.90 71.85), burun kemiği yokluğunda/hipoplazisinde 18.01 (5.46-59.32), kısa femur varlığı ile 9.74 (3.70-25.65), kısa humerus varlığında 11.42 (4.30-30.30), sol ekojenik intrakardiyak odak varlığında $4.20(1.39-12.64)$ kat artmaktadır. Kombine markerların analizinde,burun kemiği hipoplazisi, kısa humerus ve triküspit yetersizliğinin birlikteliği en yüksek riskle sonuçlandığını gösterilmiştir ( $O R=11.20$, LHR =7.53).

Sonuç: NIPT'nin iyice yayılmadığı bazı ülkelerde, yüksek riskli gebeliklerde Down sendromu risk modifikasyonu için genetik sonografi önerilir.

Anahtar Kelimeler: Genetik Sonogram, Anöploidi, Gebelik
${ }^{1}$ University of Health Sciences, Süleymaniye Research and Education Hospital, Department of Obstetrics and Gynecology, Istanbul, Turkey. ${ }^{2}$ Sisli Kolan International Hospital, Department of Obstetrics and Gynecology , Istanbul, Turkey. ${ }^{3}$ Bandırma Onyedi Eylül University, Health Science Faculty, Balikesir, Turkey.

(iD)

\section{FTÖ: 0000-0002-0176-8543}

BAȘ: 0000-0002-4165-9405

AYA: 0000-0001-6660-4964

Ethics Committee Approval: The study was approved by Suleymaniye Maternity Hospital ethical authority. (Project No: 352. 01/06/2008)

Etik Kurul Onayı: Çalışma Süleymaniye Kadın doğum Hastanesi etik kurulu tarafindan onaylanmıştır. (Proje No: 352. 01/06/2008)

Conflict of Interest: No conflict of interest was declared by the authors.

Çıkar Çatıșması: Yazarlar çıkar çatıșması bildirmemişlerdir.

Financial Disclosure: The authors declared that this study has received no financial support.

Finansal Destek: Yazarlar bu çalıșma için finansal

destek almadıklarını beyan etmişlerdir.

Geliş Tarihi / Received: 19.03.2020

Kabul Tarihi / Accepted: 20.07.2020

Yayın Tarihi / Published: 31.08.2020

Sorumlu yazar / Corresponding author:

Bulat Aytek Şık

Adres/Address: Istanbul Sisli Kolan International Hospital -1. Kat Tüp Bebek Ünitesi, Istanbul, Turkey.

e-posta: bulataytek@hotmail.com

Tel/Phone: +90 (532) 5966990

Copyright $($ ) ACEM 


\section{Introduction}

Prenatal diagnosis refers to the detection of fetal chromosomal anomalies and other fetal malformations and diseases during the intrauterine period. Biochemical tests and ultrasonography (screening at 11th-14th weeks for nuchal translucency, screening at 18th-23rd weeks for soft markers) have become standard procedures for screening fetal chromosomal abnormalities [1,2]. Diagnosis of fetal aneuploidy requires invasive prenatal diagnostic procedures. These invasive diagnostic methods can lead to abortions in 1-2\% of cases and are therefore recommended to those who have a high risk of chromosomal anomaly [3]. One of the methods to determine risk is second trimester ultrasonographic evaluation. This evaluation should identify abnormal ultrasonographic findings including major structural anomalies as well as minor (soft) markers that can aid in distinguishing aneuploid fetuses from euploid ones [4].

Ultrasonography is a highly efficient method for detection of trisomy 13 and 18 due to the high frequency of major anomalies (83-100 \%). However, major fetal anomaly is observed in only $25 \%$ of cases with trisomy 21 [5]. Major fetal anomalies observed in the ultrasonographic examination of fetuses with Down syndrome include cardiac defects (AVSD, Membranous VSD, Coarctation of Aorta, Double Outlet Right Ventricle, Tetralogy of Fallot), duodenal atresia, cystic hygroma, and hydrops fetalis. When these findings are detected, fetal karyotyping is recommended without the need for any additional risk modification [6]. On the other hand, some minor ultrasonographic changes are used for Down syndrome risk modification. These changes are often seen in normal fetuses, are usually transient, and have no serious consequences on the prognosis of the fetus. However, some features are more common in fetuses with trisomy 21 and are considered ultrasonographic markers (soft markers) of Down syndrome [7]. The most commonly used markers include nuchal fold thickness, hyperechogenic bowels, echogenic intracardiac focus, short extremities, pyelectasis, mild degree ventriculomegaly, wide pelvic angle, shortness of frontal lobe hypoplasia, clinodactyly, chorioid plexus cyst, and single umbilical artery. In recent years, attempts have been made to increase the sensitivity of this procedure by integrating additional measures, including absence or hypoplasia of nasal bone [8], frontomaxillary facial angle, prenasal edema [9], aberrant right subclavian artery [10], and tricuspid regurgitation [11]. The concept of "genetic sonography" can be described as the determination of aneuploidy risk via ultrasonography in order to identify patients with a high risk of trisomy 21. The goal is to reduce the number of unnecessary amniocentesis (and thus to reduce pregnancy loss associated with this procedure) without compromising sensitivity.

The number of genetic sonographic markers which are recommended for use in assessment of fetal anomalies has increased substantially over the past 20 years. Utilization of a large panel of sonographic findings results in increased diagnostic sensitivity (50-93\%) [12].

The aim of the present study is to determine the efficacy of genetic sonography for predicting aneuploidy among high risk pregnant women referred to the perinatology unit in Suleymaniye Maternity Hospital.

\section{Material and methods}

In our study, 2036 high-risk patients from 10942 patients who underwent genetic sonograms with second trimester (16th-24th gestational weeks) ultrasonography applied to the Perinatology Department of Suleymaniye Maternity Hospital Hospital between June 2000 and July 2011 were included.
Approval of Education and Planning Board and Ethical Committee of the Suleymaniye Maternity Hospital was received (Date:01/06/2008, No: 352). This study has been conducted in accordance with the declaration of Helsinki.

The women were considered as high-risk and were referred to perinatology department due to one or more of the following criteria: advanced maternal age, history of baby with anomaly in the previous pregnancy, presence of a relative with trisomy 21, high biochemical risk, anomaly detected by ultrasonography, presence of a marker suggestive of aneuploidy. We attempted to contact all 2036 cases during the postpartum period to confirm the diagnosis. We could not reach 643 $(31.06 \%)$ cases due to incorrect phone number, missing hospital records, or change of address. We successfully contacted 1393 cases. 30 subjects were excluded due to intra-uterine demise before 40th week of gestation. Therefore, the study included $1363(66.94 \%)$ cases. Table 1 shows the reason for referral among high-risk pregnant women.

\begin{tabular}{|c|c|}
\hline Reason of referral & $\mathrm{ntn}(\%) \quad \mathrm{Cou}$ \\
\hline Advanced maternal age & $290(14.24 \%)$ \\
\hline $\begin{array}{l}\text { Advanced maternal age }+ \text { High calculated biochemical } \\
\text { risk }^{\text {a }}\end{array}$ & $196(9.62 \%)$ \\
\hline $\begin{array}{l}\text { Advanced maternal age + Presence of an ultrasonographic } \\
\text { finding }\end{array}$ & $92(4.51 \%)$ \\
\hline $\begin{array}{l}\text { Advanced maternal age }+ \text { High calculated biochemical } \\
\text { risk }^{\mathrm{a}}+\text { Presence of an ultrasonographic finding }\end{array}$ & $45(2.21 \%)$ \\
\hline $\begin{array}{l}\text { Advanced maternal age }+ \text { History of a baby with anomaly } \\
\text { in the previous pregnancy }\end{array}$ & $6(0.29 \%)$ \\
\hline $\begin{array}{l}\text { Advanced maternal age +Presence of a relative with } \\
\text { trisomy } 21\end{array}$ & $1(0.04 \%)$ \\
\hline $\begin{array}{l}\text { Advanced maternal age+ History of a baby with anomaly } \\
\text { in the previous pregnancy+ Presence of an } \\
\text { ultrasonographic finding }\end{array}$ & $1(0.04 \%)$ \\
\hline $\begin{array}{l}\text { Advanced maternal age+ Presence of a relative with } \\
\text { trisomy } 21+\text { High calculated biochemical risk }\end{array}$ & $1(0.04 \%)$ \\
\hline History of a baby with anomaly in the previous pregnancy & $11(0.54 \%)$ \\
\hline $\begin{array}{l}\text { History of a baby with anomaly in the previous } \\
\text { pregnancy+ Presence of an ultrasonographic finding }\end{array}$ & $4(0.19 \%)$ \\
\hline $\begin{array}{l}\text { History of a baby with anomaly in the previous } \\
\text { pregnancy+ High calculated biochemical risk }{ }^{\mathrm{a}}\end{array}$ & $2(0.09 \%)$ \\
\hline Presence of a relative with trisomy 21 & $1(0.04 \%)$ \\
\hline $\begin{array}{l}\text { Presence of a relative with trisomy } 21+\text { Presence of an } \\
\text { ultrasonographic finding }\end{array}$ & $4(0.19 \%)$ \\
\hline High calculated biochemical risk ${ }^{\mathrm{a}}$ & $317(15.56 \%)$ \\
\hline $\begin{array}{l}\text { High calculated biochemical risk }{ }^{\mathrm{a}}+\text { Presence of an } \\
\text { ultrasonographic finding }\end{array}$ & $192(9.43 \%)$ \\
\hline Presence of an ultrasonographic finding & $873(42,87 \%)$ \\
\hline Total & $2036(\% 100)$ \\
\hline
\end{tabular}

In our perinatology department, genetic sonography was performed using a 3-7 MHz abdominal convex probe with a General Electric Voluson E730 ultrasonography device or a 3-5 $\mathrm{MHz}$ abdominal convex probe with a General Electric Logic 400 ultrasonography device. All measurements and evaluations were performed by an experienced perinatologists in the unit following a standardized protocol. Examinations included fetal biometric measurements and detailed investigation for major and minor markers of aneuploidy. Examinations were carried out in the supine position at 2-3 MHz frequency, allocating 20 minutes of time per patient on average. Short femur was defined as the proportion of measured length to the expected length smaller < 0.91 and short humerus was defined as the proportion of measured length to the expected length $<0.90$. Mild degree ventriculomegaly was defined as lateral ventricle atrial diameter of the fetal head measured in transverse axial section between 10 and $15 \mathrm{~mm}$. Echogenic intracardiac focus was defined as the presence of one or more round hyperechogenic appearances in 
the ventricles in a four chamber section of the heart with similar or higher echogenicity compared to bones. Likewise, echogenic bowel was defined as bowels showing the same or higher echogenicity compared to bone structures such as the tibia or iliac bones. Criterion for renal pyelectasis was defined as bilateral renal pelvis anteroposterior diameter greater than $3 \mathrm{~mm}$. Nasal hypoplasia was defined as fetal nasal bone length $\leq 2.5$ $\mathrm{mm}$. Increased nuchal fold thickness was defined as thickness $\geq$ $5 \mathrm{~mm}$. Sensitivity, specificity, odds ratio, (+) and (-) likelihood ratios were calculated for each of the markers observed by ultrasonography.

\section{Statistical analysis}

As statistical methods mean, standard deviation, frequency, the chi-square test and diagnostic screening tests were used. Statistical analyses were performed with the SSPS version 17.0 for Windows (SPSS Inc., Chicago, IL, USA) We assessed the overall diagnostic performance by weighted independent estimation of detection rate (sensitivity), true negative rate (specificity), positive likelihood ratio (LR; sensitivity / (1-specificity) and negative LR (1-sensitivity) / specificity). Results were evaluated within a $95 \%$ confidence interval, and level of significance was accepted as $\mathrm{p}<0.05$.

\section{Results}

The study included 1363 high-risk cases presenting to the Perinatology Department of Suleymaniye Maternity Hospital, who underwent a second trimester genetic sonography and whose diagnosis was confirmed during the postpartum period. Maternal age of cases varied between 17 and 48 years, with a mean maternal age of $31.25 \pm 6.64$ years. In our study, maternal age was $<35$ years in $862(63.5 \%)$ cases, and $\geq 35$ years in 496 $(36.5 \%)$ cases. 1363 high-risk cases were provided with genetic counseling. 1363 high-risk cases were advised to undergo invasive procedures to reach a definitive diagnosis and for karyotyping. 336 cases did not choose to undergo the recommended procedure. Of the 1015 cases who agreed to undergo the recommended procedure, 966 cases $(95.1 \%)$ underwent amniocentesis , 45 cases (4.43\%) underwent cordocentesis, and 4 cases $(0.4 \%)$ underwent chorionic villous sampling. No prenatal or postnatal karyotype anomalies were detected in $1338(98.16 \%)$ cases. Aneuploidy was detected in 25 $(1.84 \%)$ cases. Of these 25 cases with aneuploidy, 22 had trisomy 21,1 had trisomy 2,1 had trisomy 18,1 had triploidy (69 XXY). 21 of the 22 cases with trisomy 21 were detected via invasive prenatal diagnostic tests.

The remaining case was advised to undergo amniocentesis due to detection of a bilateral intracardiac echogenic focus, bilateral choroid plexus cyst, and tricuspid regurgitation in the ultrasonography. However, the patient did not follow the recommendations of the medical staff and trisomy 21 was diagnosed in the newborn postnatally.

Among the 25 cases with aneuploidy, none had a relative with Down syndrome or history of anomaly in a previous pregnancy. Among the 1338 cases classified as the control group, $7(0.5 \%)$ had a relative with Down syndrome, and 2 had a history of anomaly in a previous pregnancy. There was no significant difference between the control and aneuploidy groups regarding presence of a relative with Down syndrome or history of anomaly in a previous pregnancy ( $\mathrm{p}>0.05)$.

Hypoplasia/absence of the nasal bone was significantly more frequent among cases with aneuploidy $(\mathrm{p}=0.001)$. Among 25 cases with aneuploidy, 4 had hypoplasia/absence of the nasal bone. The sensitivity and specificity of this marker were $16 \%$ and $98.95 \%$, respectively. Hypoplasia/absence of the nasal bone increased the risk of aneuploidy by 18.01 (95\% CI 5.46-59.32) fold. The likelihood ratio (+) was 15.30 and the likelihood ratio (-) was 0.84 (Table 2).

Short femur was significantly more common among cases with aneuploidy $(\mathrm{p}=0.001)$. Among the 25 cases with aneuploidy, 6 had short femur. The sensitivity and specificity of this marker were $24 \%$ and $98.86 \%$, respectively. Presence of short femur increased the risk of aneuploidy by 9.74 (95\% CI 3.70-25.65) fold. The likelihood ratio (+) was 7.64 and the likelihood ratio (-) was 0.78 (Table 2).

Short humerus was significantly more common among cases with aneuploidy $(\mathrm{p}=0.001)$. Among 25 cases with aneuploidy, 6 had a short humerus. The sensitivity and specificity of this marker were $24 \%$ and $97.31 \%$, respectively. Presence of short humerus increased the risk of aneuploidy by 11.42 (95\% CI 4.30-30.30) folds. The likelihood ratio (+) was 8.92; and likelihood ratio (-) was 0.78. (Table 2).

Tricuspid regurgitation was significantly more common among cases with aneuploidy $(\mathrm{p}=0.001)$. Among 25 cases with aneuploidy, 2 had tricuspid regurgitation. Sensitivity and specificity of this marker were $8 \%$ and $99.49 \%$, respectively. Presence of tricuspid regurgitation increased the risk of aneuploidy by 14.45 (95\% CI 2.90-71.85) fold. The likelihood ratio (+) was 13.37 and the likelihood ratio (-) was 0.92 . (Table 2).

Clinodactyly was significantly more common among cases with aneuploidy $(\mathrm{p}=0.024)$. Among 25 cases with aneuploidy, 1 had clinodactyly. Sensitivity and specificity of this marker were $4 \%$ and $99.48 \%$, respectively. Presence of clinodactyly increased the risk of aneuploidy by $7.92(95 \% \mathrm{CI}$ 0.93-66.92) fold. However, this increase was did not meet the standard of statistical significance $(\mathrm{p}<0.05)$. The likelihood ratio (+) was 7.69 and the likelihood ratio (-) was 0.96. (Table 2).

The frequency of major cardiac anomaly was significantly higher among cases with aneuploidy $(\mathrm{p}=0.035)$. Among 25 cases with aneuploidy, 3 had major cardiac anomaly. Sensitivity and specificity of this marker were $12 \%$ and $99.33 \%$, respectively. Presence of major cardiac anomaly increased the risk of aneuploidy by 20.13 (95\% CI 5.10-79.47) fold. The likelihood ratio (+) was 17.91 and the likelihood ratio (-) was 0.88. (Table 2).

Presence of left echogenic intracardiac focus was significantly more common among cases with aneuploidy $(\mathrm{p}=0.006)$. Among the 25 cases with aneuploidy, 4 had left echogenic intracardiac focus. Sensitivity and specificity of this marker were $16 \%$ and $95.66 \%$, respectively. The odds ratio was 4.20 (95\% CI 1.39-12.64). The likelihood ratio (+) was 3.68 and the likelihood ratio (-) was 0.87 . (Table 2).

In addition to isolated markers, we also examined the association between combinations markers and aneuploidy risk. Among all investigated combinations, the combination that was most strongly associated with aneuploidy was tricuspid regurgitation + hypoplasia/absence of the nasal bone + short humerus. The combination of tricuspid regurgitation + hypoplasia/absence of the nasal bone + short humerus was significantly more common among cases with aneuploidy $(\mathrm{p}=0.001)$. Among 25 cases with aneuploidy, 9 had at least one of the following conditions: tricuspid regurgitation, hypoplasia/absence of nasal bone, or short humerus combination. Sensitivity and specificity of this combination were $36 \%$ and $95.22 \%$, respectively. The odds ratio was 11.20 (95\% CI 4.7626.31). The likelihood ratio (+) was 7.53 and the likelihood ratio (-) was 0.67 .

Short femur + short humerus + hypoplasia of the nasal bone was the second most common combination among cases with aneuploidy $(\mathrm{p}=0.001)$. Among 25 cases with aneuploidy, 8 exhibited at least one of the following traits: short femur, short 


\begin{tabular}{|c|c|c|c|c|c|c|c|c|c|}
\hline & $\begin{array}{l}\text { Aneuploidy } \\
(\mathrm{n}=25)\end{array}$ & $\begin{array}{l}\text { Normal } \\
(\mathrm{n}=1338)\end{array}$ & ${ }^{+} p$ value & Sensitivity & Specificity & Odds Ra & & $\begin{array}{l}\text { L ratio } \\
(+)\end{array}$ & $\begin{array}{l}\text { Li ratio } \\
(-)\end{array}$ \\
\hline & $\mathrm{n}(\%)$ & $\mathrm{n}(\%)$ & & $\%$ & $\%$ & & $\% 95 \mathrm{CI}$ & & \\
\hline $\begin{array}{l}\text { Hypoplasia/absence of the nasal } \\
\text { bone }\end{array}$ & $4(16 \%)$ & $14(1.0 \%)$ & 0.001 & $16 \%$ & $98.95 \%$ & 18.01 & $5.46-59.32$ & 15.30 & 0.84 \\
\hline Short femur & $6(24 \%)$ & $42(3.1 \%)$ & 0.001 & $24 \%$ & $96.86 \%$ & 9.74 & $3.70-25.65$ & 7.64 & 0.78 \\
\hline Short humerus & $6(24 \%$ & $36(2.7 \%)$ & 0.001 & $24 \%$ & $97.31 \%$ & 11.42 & $4.30-30.30$ & 8.92 & 0.78 \\
\hline Tricuspid regurgitation & $2(8 \%)$ & $8(0.6 \%)$ & 0.001 & $8 \%$ & $99.49 \%$ & 14.45 & $2.90-71.85$ & 13.37 & 0.92 \\
\hline Clinodactyly & $1(4 \%)$ & $7(0.5 \%)$ & 0.024 & $4 \%$ & $99.48 \%$ & 7.92 & 0.93-66.92 & 7.69 & 0.96 \\
\hline Major cardiac anomaly & $3(12 \%)$ & $9(0.7 \%)$ & 0.035 & $12 \%$ & $99.33 \%$ & 20.13 & $5.10-79.47$ & 17.91 & 0.88 \\
\hline Left echogenic intracardiac focus & $4(16 \%)$ & $58(4.33 \%)$ & 0.006 & $16 \%$ & $95.66 \%$ & 4.20 & $1.39-12.64$ & 3.68 & 0.87 \\
\hline $\begin{array}{l}\text { Ttricuspid regurgitation + } \\
\text { hypoplasia/absence of the nasal } \\
\text { bone + short humerus }\end{array}$ & $9(36 \%)$ & $64(4.78 \%)$ & 0.001 & $36 \%$ & $95.22 \%$ & 11.20 & $4.76-26.31$ & 7.53 & 0.67 \\
\hline $\begin{array}{l}\text { Short femur + short humerus + } \\
\text { hypoplasia }\end{array}$ & $8(32 \%)$ & $56(4.18 \%)$ & 0,001 & $32 \%$ & $95.81 \%$ & 10.77 & $4.46-26.02$ & 7.63 & 0.70 \\
\hline
\end{tabular}

+ chi-square test $\quad \mathrm{p}<0,05$

humerus, or hypoplasia of the nasal bone. Sensitivity and specificity of this combination were $32 \%$ and $95.81 \%$, respectively. Odds ratio was 10.77 (95\% CI 4.46-26.02). The likelihood ratio (+) was 7.63 and the likelihood ratio (-) was 0.70. (Table 2).

There was no significant difference regarding presence of right echogenic intracardiac focus, hyperechogenic bowels, or the proportion of cases with nuchal fold thickness $>5 \mathrm{~mm}$ between the control and aneuploidy groups in the high-risk population $(\mathrm{p}=0.236 ; \mathrm{p}=0.526 ; \mathrm{p}=0.175)$. In addition, there was no significant difference between the normal and aneuploidy groups in the high-risk population regarding presence of right pyelectasis, or left pyelectasis, or bilateral pyelectasis, presence of right ventriculomegaly, or left ventriculomegaly, or bilateral ventriculomegaly, presence of right plexus cyst, or left choroid plexus cyst, or bilateral choroid plexus cysts, or absence of right umbilical artery, or left umbilical artery $([\mathrm{p}=0.217, \mathrm{p}=0.196$, $\mathrm{p}=0.296] ; \quad[\mathrm{p}=0.151, \mathrm{p}=0.730, \mathrm{p}=0.604] ; \quad[\mathrm{p}=0.138, \mathrm{p}=0.264$, $\mathrm{p}=0.102] ;[\mathrm{p}=0.594, \mathrm{p}=0.365]$, respectively) (Table 3 ).

\section{Discussion}

Genetic sonography relies on several ultrasonographic markers which are not strictly fetal anomalies. These features may also be observed in normal fetuses but are more common in fetuses with trisomy 21 . In our study, we investigated cases who underwent genetic sonogram between the 16th and 24th weeks of gestation for examination of nuchal fold thickness, hyperechogenic bowel, echogenic intracardiac focus, short femur, short humerus, pyelectasis, ventriculomegaly, hypoplasia/absence of nasal bone, choroid plexus cyst, clinodactyly, single umbilical artery, tricuspid regurgitation and major cardiac anomaly. The patients were advised to undergo additional invasive diagnostic procedures because of presence of one or more significant ultrasonographic findings and another risk factor, such as advanced maternal age, increased calculated risk in triple test, history of anomaly in a previous pregnancy, or presence of a relative with Down syndrome.

According to our data, hypoplasia/absence of the nasal bone, short femur, short humerus, tricuspid regurgitation and left echogenic intracardiac focus were significantly more common among cases with aneuploidy $(\mathrm{p}<0.05)$.

Cicero et al. reported the LHR value for trisomy 21 in the presence of nasal bone hypoplasia as 50.5 [13]. Bromley et al. reported the LHR value in the absence of nasal bone as 83, stating that the absence of the nasal bone was the most significant marker in the genetic sonogram [14]. In our study, sensitivity and specificity of hypoplasia/absence of nasal bone were $16 \%$ and $98.95 \%$, respectively. We found that hypoplasia/absence of nasal bone increased the risk of aneuploidy by 18.01 (5.46-59.32) fold.

Benacerraf et al reported the LHR value for short femur as 5.5, and the LHR value for short humerus as 13.4 [15]. Nyberg et al. calculated LHR of short femur as 1.2, and LHR of short humerus as 5.1 [16]. Johnson et al. reported the LHR of short humerus as 7.5, making this the third most important marker in the genetic sonogram [17]. In our study, we calculated sensitivity, specificity and LHR values of short femur as $24 \%$, $96.86 \%$, and 7.64 , respectively. The presence of short femur increased the risk of aneuploidy by 9.74 (3.70-25.65) fold. As for short humerus, sensitivity, specificity and LHR values were $24 \%, 97.31 \%$ and 8.92 , respectively. Short humerus increased the risk of aneuploidy by 11.42 (4.30-30.30) fold. Other studies also showed that in comparison to the presence of short femur, the presence of a short humerus was more significant for aneuploidy risk [18].

Faiola et al. examined the association between tricuspid regurgitation and chromosomal abnormalities [19]. Their study included a total of 1557 cases with high risk for Down syndrome (high biochemical risk, or increased nuchal translucency), and they examined tricuspid valve in 1538 (99\%) cases. They detected trisomy 21 in 114 cases, trisomy 18 in 42 cases, and other chromosomal abnormalities in 59 cases, while 1323 cases were found to have no chromosomal abnormality. They observed tricuspid regurgitation in $67.5 \%$ of cases with trisomy 21 , in $33 \%$ of cases with trisomy 18 , in $15 \%$ of cases with other chromosomal abnormalities, and in $4.4 \%$ of cases without any chromosomal abnormality. Faiola et al. concluded that early detection of tricuspid regurgitation was not an appropriate screening method for the general population. They stated however, that since tricuspid regurgitation was frequently associated with chromosomal abnormalities in a high risk population, and because sensitivity was high, that this finding could serve as a useful marker. In our study, we found that tricuspid regurgitation was significantly more common among cases with aneuploidy $(\mathrm{p}=0.001)$. Among 25 cases with aneuploidy, 2 were found to have tricuspid regurgitation. Sensitivity and specificity of this marker were $8 \%$ and $99.49 \%$, respectively. The odds ratio was 14.45 (95\% CI 2.90-71.85). The likelihood ratio (+) was found as 13.37 and the likelihood ratio () was 0.92 .

Roberts et al. reported the frequency of echogenic intracardiac focus among aneuploid fetuses as 16-39\% [20]. Nyberg et al. and Benacerraf et al. reported LHR values for echogenic intracardiac focus between 1.4 and 5.4 [15,16]. In our study, the frequency of left echogenic intracardiac focus was significantly higher among cases with aneuploidy. Sensitivity, 
specificity and LHR were 16\%, 95.66\% and 3.68, respectively, and this marker was found to increase the risk of aneuploidy by $4.20(1.39-12.64)$ fold.

Table 3: Distribution of cases according to genetic sonogram results

\begin{tabular}{|c|c|c|c|}
\hline & $\begin{array}{l}\text { Aneuploidy } \\
(\mathrm{n}=25) \\
\mathrm{n}(\%)\end{array}$ & $\begin{array}{l}\begin{array}{l}\text { Normal } \\
(\mathrm{n}=1338) \\
\mathrm{n}(\%)\end{array} \\
\end{array}$ & $p$ value \\
\hline $\begin{array}{l}\text { Right Echogenic Intracardiac } \\
\text { Focus }\end{array}$ & $1(4 \%)$ & $17(1.27 \%)$ & 0.236 \\
\hline Hyperechogenic Bowels & $4(16 \%)$ & $284(21.2 \%)$ & 0.526 \\
\hline $\begin{array}{l}\text { Nuchal Fold Thickness }>5 \\
\text { Mm }\end{array}$ & $3(12 \%)$ & $81(6.1 \%)$ & 0.175 \\
\hline Right Pyelectasis & 0 & $77(5.75 \%)$ & 0.217 \\
\hline Left Pyelectasis & 0 & $84(6.27 \%)$ & 0.196 \\
\hline Bilateral Pyelectasis & 0 & $56(4.1 \% 8)$ & 0.296 \\
\hline Right Ventriculomegaly & $2(8 \%)$ & $40(3.0 \%)$ & 0.151 \\
\hline Left Ventriculomegaly & 0 & $38(2.8 \%)$ & 0.730 \\
\hline Bilateral Ventriculomegaly & $1(4 \%)$ & $32(2.39 \%)$ & 0.604 \\
\hline RİGHT Choroid Plexus & $5(20 \%$ & $\begin{array}{l}143 \\
(10.68 \%)\end{array}$ & 0.138 \\
\hline Left Choroid Plexus & $4(16 \%)$ & $\begin{array}{l}126 \\
(10.16 \%)\end{array}$ & 0.264 \\
\hline $\begin{array}{l}\text { Bilateral Choroid Plexus } \\
\text { Cysts }\end{array}$ & $4(16 \%)$ & $98(7.32 \%)$ & 0.102 \\
\hline $\begin{array}{l}\text { Absence Of Left Umbilical } \\
\text { Artery }\end{array}$ & $1(4 \%)$ & $22(1.64 \%)$ & 0.365 \\
\hline $\begin{array}{l}\text { Absence Of Right Umbilical } \\
\text { Artery }\end{array}$ & 0 & $15(1.12 \%)$ & 0.594 \\
\hline
\end{tabular}

Vintzileos et al. (1997) and Deren et al. (1998) reported that clinodactyly was observed in $3.4 \%$ of normal fetuses, and in $18.8 \%$ of fetuses with trisomy 21 . They reported the LHR value as $5.6[21,22]$. In our study, clinodactyly was significantly more common among cases with aneuploidy $(\mathrm{p}<0.05)$. Clinodactyly was calculated to increase the risk of aneuploidy by $7.92(95 \%$ CI 0.93-66.92) fold. However, this increase was insignificant.

In our study, we found no significant difference regarding nuchal fold thickness, presence of hyperechogenic bowels, pyelectasis, ventriculomegaly, choroid plexus cyst, single umbilical artery, or right intracardiac focus between the normal and aneuploidy groups in the high risk population $(\mathrm{p}>0.05)$.

Studies that defined pathological nuchal fold thickness as $\geq 6 \mathrm{~mm}$ reported the sensitivity of this marker as $40 \%$ and false positivity as $0.1 \%$. Smith-Bindman et al. Reported the LHR value of nuchal fold thickness as 17 , and stated that it was the second most significant marker in the genetic sonogram [23]. Nyberg et al. proposed that the sensitivity of this marker would be increased without causing any abnormal increase in the false positivity rate by dropping the pathological threshold to $5 \mathrm{~m}$; using this definition, they, reported an LHR value of 38.7 [16]. In our study, we defined the pathological threshold for nuchal fold thickness as $5 \mathrm{~mm}$. We found no significant difference between the normal and aneuploidy groups regarding the proportion of cases with increased nuchal thickness $(\mathrm{p}=0.175)$.

Benacerraf et al. and Nyberg et al. reported the LHR of hyperechogenic bowels as 22.5 and 6.7 , respectively $[15,16]$. In their 2001 study, Smith Bindman et al. reported sensitivity, specificity, and LHR values of hyperechogenic bowels as 4\%, $99 \%$, and 6.1, respectively [23]. In our study, we found no significant difference in the high-risk population regarding frequency of hyperechogenic bowels between normal and aneuploidy groups $(\mathrm{p}>0.05)$.

In the studies conducted by Mandell et al. and Benacerraf et al. pyelectasis was observed in 17-25\% of fetuses with Down syndrome, and $2.8 \%$ of normal fetuses [15,24]. Mean LHR values of pyelectasis were reported in the range between 1.5 and 5.2 [15]. In their 2001 study, Smith Bindman et al. reported sensitivity, specificity and LHR values of pyelectasis as $2 \%, 99 \%$, and 1.9 , respectively [23]. We did not observe any cases of pyelectasis in the study group.

Hobbins et al. reported the sensitivity of mild degree ventriculomegaly between $5.7 \%$ and $14.5 \%$, and false positivity rate as $0.1 \%$. [25]. In our study, we found no evidence that ventriculomegaly has any meaningful sensitivity for the prediction of aneuploidy.

In a case control study published in 2002, Bromley et al. reported the LHR value of echogenic intracardiac focus for aneuploidy risk as 1.4 (95\% CI 0.6-4.3) [26]. However, this result was not statistically significant 26 .In our study, the frequency of left echogenic intracardiac focus was significantly higher among cases with aneuploidy $(\mathrm{p}=0.006)$. Among the 25 cases with aneuploidy, 4 were found to have left echogenic intracardiac focus. The sensitivity and specificity values were $16 \%$ and $95.66 \%$, respectively. The odds ratio was $4.20(95 \% \mathrm{CI}$ 1.39-12.64). Likelihood ratio (+) The likelihood ratio (+) was 3.68 and the likelihood ratio (-) was 0.87 .

Gross et al. reported the frequency of trisomy 18 in the presence of isolated choroid plexus cyst as 1/374 [27] .Smith Bindman et al. (2001) calculated the LHR value of choroid plexus cyst for trisomy 21 as 1.0 , and stated that presence choroid plexus cyst was not a marker for trisomy 21 [23]. In our study, the frequency of choroid plexus cyst was not significantly different between the control and aneuploidy groups in a high risk population $(\mathrm{p}>0.05)$.

Budorick et al. found no significant association between isolated single umbilical artery and aneuploidy [28]. Similarly, we found no significant difference regarding frequency of a single umbilical artery between the control and aneuploidy groups in a high risk population ( $\mathrm{p}>0.05)$. Nyberg et al. evaluated risk modification based on the genetic sonogram and found that the presence of a single marker increased the risk by 2 fold, the presence of two markers increased the risk by 10 fold, and presence of three markers increased the risk by 100 fold on average [18]. In our study, when we examined the effect of combinations of markers on aneuploidy risk, we found that the combination of hypoplasia/absence of nasal bone + short humerus + tricuspid regurgitation yielded the highest LHR value, with an odds ratio of 11.20 .

Nowadays in most of the countries a highly sensitive non-invasive testing called NIPT is used as screening test for earlier detection of aneuploidy in high risk pregnant women. Pregnancies with high risk NIPT results are referred for genetic counselling to be evaluated for invasive procedures such as chorionic villus sampling, amniocentesis or cordosentesis. But still in some countries NIPT could not be used as routine screening method. In these cases, this study have clinical importance to guide obstetricians for efficacy of genetic sonogram for predicting aneuploidy in a high risk pregnancy population. The purpose of genetic sonogram is to reduce the number of unnecessary invasive procedures and to minimize the rate of false positivity without compromising the sensitivity for detection of anomalies in a high risk population. In conclusion, when performed following a standardized protocol in perinatology units by experienced per,natologists, genetic sonogram is characterized by high sensitivity, high specificity and low false positivity rates for Down syndrome screening. This procedure is recommended for Down syndrome risk modification in high or intermediate risk populations as determined by maternal age, first trimester screening or triple/quadruple tests. 


\section{References}

1. ACOG Committee Opinion: Down Syndrome Screening. Publication No. 141, 1994, American College of Obstetricians and Gynecologists, Washington, DC.

2. Lynch L, Berkowitz RL: Amniocentesis, Skin Biopsy, Umblical Cord Blood Sampling in the Prenatal Diagnosis of Genetic Disorders. in Reece EA, Hobbins JC, Mahoney MJ. (eds): Medicine of the Fetus and Mother. Philadelphia. JB. Lippincott, 1992, pp 641-652

3. Scott F, Peters H, Boogert $\mathrm{T}$ et al. The loss rates for invasive prenatal testing in a specialised obstetric ultrasound practice. Aust N Z J Obstet Gynaecol 2002; 42: 55-8.

4. Nyberg DA, Souter VL. Sonographic markers of fetal aneuploidy. Clin Perinatol 2000; 27: 761-89.

5. Vintzileos AM, Egan JF. Adjusting the risk for trisomy 21 on the basis of second trimester ultrasonography. Am J Obstet Gynecol, 1995; 172: 837-844

6. American College of Obstetricians and Gynecologists. ACOG Practice Bulletin No. 88, December 2007. Invasive prenatal testing for aneuploidy. Obstet Gynecol 2007;110: 1459-67.

7. Benacerraf BR, Neuberg D, Bromley B, Frigoletto FD Jr. Sonographic scoring index for prenatal detection of chromosomal abnormalities. J Ultrasound Med 1992; 11: 449-58.

8. Odibo AO, Sehdev HM, Gerkowicz S, Stamilio DM, Macones GA.. Comparison of the efficiency of second-trimester nasal bone hypoplasia and increased nuchal fold in Down syndrome screening. Am J Obstet Gynecol 2008;199:281.e1-5.

9. Vos FI, De Jong-Pleij EA, Ribbert LS, Tromp E, Bilardo CM. Three-dimensional ultrasound imaging and measurement of nasal bone length, prenasal thickness and frontomaxillary facial angle in normal second- and thirdtrimester fetuses. Ultrasound Obstet Gynecol 2012;39:636-41.

10. Fehmi Yazıcıŏlu H, Sevket O, Akın H, Aygün M, Özyurt ON, Karahasanoğlu A. Aberrant right subclavian artery in Down syndrome fetuses. Prenat Diagn 2013;33:209-13.

11. Faiola S, Tsoi E, Huggon IC, Allan LD, Nicolaides KH Likelihood ratio for trisomy 21 in fetuses with tricuspid regurgitatiom at the 11 to $13+6$ week scan. Ultrasound Obstet Gynecol 2005;26:22-7

12. Vintzileos AM, Campbell WA, Rodis JF, Guzman ER, Smulian JC, Knuppel RA. The use of second-trimester genetic sonogram in guiding clinical management of patients at increased risk for fetal trisomy 21. Obstet Gynecol 1996; 87: 948-52.

13. Cicero S, Sonek JD, McKenna DS, Croom CS, Johnson L, Nicolaides KH. Nasal bone hypoplasia in trisomy 21 at $15-22$ weeks' gestation. Ultrasound Obstet Gynecol. 2003;21:15-18.

14. Bromley B, Lieberman E, Shipp TD, Benacerraf BR. Fetal nose bone length: a marker for Down syndrome in the second trimester. J Ultrasound Med 2002;12:1387-94

15. Benacerraf $\mathrm{B}$. The role of the second trimester genetic sonogram in screening for fetal Down syndrome. Semin Perinatol. 2005;29:386-394.

16. Nyberg DA, Sourer VE. Use of genetic sonography for adjusting the risk for fetal Down syndrome. Semin Perinatol. 2003;27:130144

17. Johnson MP, Michaelson JE, Barr M Jr et al. Combining humerus and femur length for improved ultrasonographic identification of pregnancies at increased risk for trisomy 21. Am J Obstet Gynecol 1995;172:1229-35.

18. Nyberg DA, Sourer VL, El-Bastawissi A, Young S, Luthhardt F, Luthy DA. Isolated sonographic markers for detection of fetal Down syndrome in the second trimester of pregnancy. J Ultrasound Med 2001;20:1053-63.

19. Faiola S . Falcon O, Huggon I, Allan L, Nicolaides KH . Fetal tricuspid regurgitation at the $11+0$ to $13+6$ week scan : Association with chromosomal defects and reproducibility of the method . Ultrasound Obstet . Gynecol .2006 ; 27:609-612

20. Roberts DJ, Genest D. Cardiac histopathologic characteristics of trisomy 13 and 21. Hum Pathol. 1992;23:1130-40.

21. Vintzileos AM, Campbell WA, Guzman ER, Smulian JC, McLean DA, Ananth Cv. Second-trimester ultrasound markers for detection of trisomy 21: which markers are best? Obstet Gynecol 1997;89:941-4.

22. Deren O, Mahoney MJ, Copel JA, Bahado-Singh RO. Subtle ultrasonographic anomalies: do they improve the Down syndrome detection rate? Am J Obstet Gynecol 1998;178:441-5.
23. Smith Bindman R, Hosmer W, Feldstein VA, Deeks JJ, Goldberg JD. Second trimester ultrasound to detect fetuses with Down syndrome. JAMA 2001;285:1044-55.

24. Mandell J, Blyth BR, Peters CA, Retik AB, Estroff JA, Benacerraf BR. Structured genitourinary defects detected in-utero. Radiology. 1991;178:193-6.

25. Hobbins JC, Lezotte DC, Persutte WH et al. An 8-center study to evaluate the utility of mid-term genetic sonograms among high risk pregnancies. J Ultrasound Med. 2003;22:33-38.

26. Bromley B, Lieberman E, Shipp TD, Benacerraf BR. The genetic sonogram: A method of risk assessment for Down syndrome in the second trimester. J Ultrasound Med 2002;21:1087-96.

27. Gross SJ, Shulman LP, Tolley EA et al. Isolated fetal chorioid plexus cysts and trisomy 18:a review and metaanalysis. Am J Obstet Gynecol. 1995;172:83-7.

28. Budorick NE, Kelly TE, Dunn JA, Scioscia AI. The single umbilical artery in a high-risk patient population. What should be offered? J Ultrasound Med 2001;20:619-27 